\title{
The Oceanographic Achievements of Vito Volterra in Italy and Abroad ${ }^{1}$
}

\author{
By Sandra Linguerri*
}

The aim of this paper is to introduce Vito Volterra's activity as a policy maker in the field of oceanography. In 1908, he was the promoter of the Thalassographic Committee (then in 1910 Royal Italian Thalassographic Committee), a national endeavor for marine research vis-à-vis the industrial world of fisheries, which soon internationalized. Abroad it was affiliated with the International Commission for the Scientific Exploration of the Mediterranean Sea, led by Albert I, Prince of Monaco (1919-1922) and then by Vito Volterra himself (1923-1928).

Keywords: History, International Commission for the Scientific Exploration of the Mediterranean Sea, Oceanography, Royal Italian Thalassographic Committee, Vito Volterra.

\section{Vito Volterra and the Royal Italian Thalassographic Committee}

Vito Volterra (1860-1940) (Goodstein 2007, Guerraggio and Paoloni 2013, Simili and Paoloni 2008) is generally considered one of the greatest mathematicians of his time. His most important contributions were in functional analysis, mathematical ph' scientific activities, rather it will focus on his contribution to talassographic (or oceanographic) studies, and especially on the creation of the Royal Italian Talassographic Committee (Linguerri 2005, Ead 2014).

In 1900, after teaching in Pisa and Turin, Volterra was offered a chair in mathematical physics at the University of Rome, where he was invited to give the inaugural lecture for the new academic year entitled Sui tentativi di applicazione delle matematiche alle scienze biologiche e sociali (On the attempts to apply mathematics to the biological and social sciences), which demonstrated his great interest in the application of mathematics to biological sciences and to economic research.

After this, Volterra's interest in oceanographic studies began and grew by travelling abroad. It was during a trip to Sweden, in 1905, to give a series of lectures at the University of Uppsala, that Volterra learned about the Copenhagenbased International Council for the Exploration of the Sea (ICES) (Rozwadowski 2002, Smed 2004) and the oceanographic studies undertaken by chemistphysicist Otto Petterson and the hydrographer Gustav Ekam, namely their

\footnotetext{
* Associate Professor in History of Science, University of Bologna, Italy.

${ }^{1}$ This paper partially reproduces an article entitled L'oceanografia italiana sbarca in Europa: Vito Volterra e la Commission internationale pour l'exploration scientifique de la mer Méditerranée, and published by Giornale di Fisica, 55, 1 (Gennaio-Marzo 2014), 61-85, with permission of Societa Italiana di Fisica 2014.
} 
applications in fishing. ${ }^{2}$ The ICES heralded a new era in oceanographic research. Indeed, international cooperation made it possible to embark on systematic surveys thanks to periodic cruises that enabled researchers to study an area with continuity and, above all, acquire data that could be compared over time. While extensive cruises in the late nineteenth century had produced appreciable results, nevertheless they allowed only episodic types of exploration.

Volterra set up the Thalassographic Committee (TC), ${ }^{3}$ an institution created in December 1908 to promote physical, chemical, meteorological and biological studies of the Italian Sea, mainly in connection with navigation and fishing industries. The TC was initially conceived as a branch of the Società Italiana per il Progresso delle Scienze (the Italian Society for the Advancement of Science, ISAS) (Linguerri 2000), an institution founded in 1907 to establish close links between the scientific community, politics, and economic development, aimed at modernizing Italy. Then in 1910, the TC became an autonomous body equipped with financial support from the government. Thus the range of activities of the Committee could expand to other areas of study, such as the upper atmosphere. Later, at the onset of WWI, the upper atmosphere studies continued for military reasons under Volterra's guidance. $^{4}$

Volterra worked hard on the TC project in 1909 and $1910,{ }^{5}$ assisted by a team of scientists, such as the hydrographer Giovanni Magrini, director of the Magistrato delle acque di Venezia, and the biologist Decio Vinciguerra, former director of the Aquarium of Rome, and the well-known Giovanni Battista Grassi, malariologist and professor at the University of Rome.

The main goals of the TC were 1) the creation of an extramural marine biological laboratory in Messina (Sicily) with an emphasis on short- and medium-term fishing applications; 2) the creation of a connection with the renowned 'Anton Dohrn' Zoological Station in Naples; 3) future plans for collaboration with the Oceanographic Museum in the Principality of Monaco, which was founded by Prince Albert I.

\footnotetext{
${ }^{2}$ Volterra refers to this episode in his unpublished work, which was specifically written for a speech on oceanograpgy he was to give to the Senate in 1909. See Volterra "Discorso al senato sulla oceanografia", Vito Volterra's Archive, Biblioteca dell'Accademia Nazionale dei Lincei e Corsiniana, Accademia Nazionale dei Lincei, Rome, Folder 94.

${ }^{3}$ Vito Volterra's Archive, Accademia Nazionale dei Lincei (Rome), Folder 68, file "Comitato Talassografico Italiano 1909 - 1926"

${ }^{4}$ When Italy entered WWI in 1915 alongside France, Great Britain and later the United States of America, Volterra volunteered for the army (Air Force). In 1917 he created a research office, the Ufficio Invenzioni e Ricerche (UIR) within the Ministry of War, with the function of supporting military and industrial activities by Italy. UIR was a body similar to those created in the allied countries, and it cooperated with them in the coordination of technical and scientific efforts during wartime. After the war, Volterra tried to transformed UIR into an institution able to promote cooperation between research and industry in peacetime (Mazliak and Tazzioli 2009, Linguerri 2015).

${ }^{5}$ V. Volterra, "Discorso sull'iniziativa degli studi talassografici nel Mediterraneo intrapresa dalla Società italiana per il progresso delle scienze 1909", (draft), in Vito Volterra's Archive, Folder 94, file "Società italiana per il progresso delle scienze. Attività 1909".
} 
In this way, the TC was supported by the Italian government. In fact, in 1910, Volterra had transformed the TC from a private body and a branch of ISAS, into a state-run body permanently linked to the Italian Ministry of the Navy. As a consequence, the TC changed its name to the Royal Italian Talassographic Committee (RITC). ${ }^{6}$ However, ISAS continued to exert a significant influence through its delegate, Volterra, who was Vice-Chairman of the RITC from 1910 to 1925. According to the statute, the Chairman pro tempore was the Minister of the Navy, while Magrini was elected secretary.

This change did not affect the autonomy of the RITC in any way, guaranteed in the regulatory norms by the Chairmanship Council. The latter was a management body equipped with a wide range of powers, and it was directly accountable for its actions to the Committee at general assemblies.

The RITC not only acted as a driving force for Italian oceanographic studies, but also it soon became internationalized.

In 1909 Volterra and other members of the TC started to plan a series of research cruises in the Adriatic, which was the scene of important commercial and navigation treaties between Austria-Hungary and Italy at the time. It was Italian statesman Luigi Luzzatti who expressly asked Volterra to make the issue of fishing in the Adriatic one of TC's priorities. ${ }^{7}$

To this end, the newly-formed Italo-Austrian Conference for Oceanographic and Biological studies in the Adriatic met in Venice on May 18-21 1910 (Magrini 1910) to draw up a provisional programme to be presented at a general assembly in the Principality of Monaco on May 2-6 1911 (Magrini 1911). Then the International Commission for Studies in the Adriatic (ICSA) was officially constituted under the chairmanship of Luigi De Marchi, professor of terrestrial physics at Padua University, and with Prince Albert I as honorary Chairman. ${ }^{8}$

Meanwhile, another special commission in charge of promoting the oceanographic exploration of the Mediterranean Sea had been appointed. The origins of the Commission for the Mediterranean Sea (the future International Commission for Scientific Exploration of the Mediterranean Sea, or ICESM)

\footnotetext{
${ }^{6}$ On 13 July 1910 King Vittorio Emanuele II signed the law no. 442 modified from that of 27 February 1913 no. 455 that founded the RITC's Centre of Vigna di Valle (near Rome) for meteorology and study of the upper atmosphere linked to the Italian Ministry of War.

${ }^{7}$ Secretary Magrini was the one who informed Volterra in October 1909 of Luzzatti's intention to discuss the issue of fishing in the Adriatic with him. See the letter from Magrini to Volterra, 10 ottobre 1909, Vito Volterra's Archive, Folder 32.

${ }^{8}$ This meeting was followed by two additional ones held in Monaco in April 1912 and May 1913 respectively. [Verbali 1912 and 1913]. The research programme for the International Commission for the Study of the Adriatic took shape over fourteen expeditions carried out from 1911 onwards. Four cruises each years (in February, in May, in August and in November) were to be undertaken following eight determined traverses, making observations and measurements according to an established technique with the standard instruments. The fourteenth cruise of the Cyclops (Italy) and of the Naiad (Austria-Hungary), which were to close the program of periodical investigations to be made in the Adriatic, took place in February, 1914 (Magrini 1916). Volterra was constantly informed by Luigi De Marchi about the events concerning the Commission of the Adriatic. See De Marchi to V.Volterra, Padua October $24^{\text {th }}, 1913$ and November $7^{\text {th }}, 1913$, Vito Volterra's archives, Folder 16.
} 
go back to July 1908 when the 9th International Congress of Geography, meeting in Geneva, agreed to a proposal advanced by Vinciguerra in the interest of marine fisheries (Vinciguerra 1908). A special committee led by Prince Albert I of Monaco ${ }^{9}$ was mandated to lay the foundations of a future Commission of the Mediterranean Sea.

On March 30, 1910, during the inauguration of the Oceanographic Museum in Monaco, (Vinciguerra 1910, Berget 1910) the special committee met for the first time. Two main concerns were expressed: first, the desire to have an intergovernmental science organization to give more weight to the recommendations of scientists, and second, the need to free the Commission from any political interference. Finally, when announcing the following year's event in Rome, Vinciguerra illustrated the task and organisation of a new body that had recently appeared in the field of the Italian marine studies, a body that promised to become a major point of reference for the international collaboration under development. It was the TC. The outbreak of the ItaloTurkish war halted cooperation to such an extent that the ICESM's meeting scheduled to be held in Rome in 1911 was called off.

From 3-6 February 1914, delegates from the Principality of Monaco, France, Italy, Spain, Austria-Hungary, Greece and Tunisia met in the Palazzo Corsini in Rome, the headquarters of the Accademia Nazionale dei Lincei, to continue the work of the ICESM $^{10}$ (Berget 1914, Verbali 1914a) in accordance with the resolutions of the provisional meeting on March 1910.

Under the chairmanship of Volterra, who replaced Prince Albert I for reasons of illness, the previous resolutions regarding collaboration between zoological stations (Joubin 1910a, Joubin 1910b) and cruises were developed, and work was laid out for each of the nations bordering the Mediterranean.

Volterra played a central role. He proposed setting up the Commission as an independent body composed of delegates from the different contracting states and administered by a Head Office appointed for a period of five years. The Commission met every two years and decided on the place and date of the following meeting. The previous resolutions regarding collaboration between zoological stations and cruises were inspired by the work that had been done in the Adriatic. The Head Office of the ICESM was established in the Principality of Monaco and Prince Albert I was confirmed as Chairman.

However, as the support of Turkey and England was also required to undertake studies in the Eastern Mediterranean, they decided to call another international conference in Madrid in 1915 for definitive agreements and to officially sign all documents and get the work underway.

The outbreak of WWI cancelled Madrid's conference, but oceanographic achievements had not been abandoned by Italy. In fact on December 10, 1916

\footnotetext{
${ }^{9}$ The members were Vinciguerra, Carlo Cori (director of the Zoological Station inTrieste, which was at the time under the Austrian jurisdiction), Paul Regnard (director of the Oceanographic Institute in Paris), C. Navarete (secretary-general of the Spanish maritime league), and Otto Krümmel (professor of the University of Kiel and president of the oceanographic section of the Genevan congress).

10 Vito Volterra's Archive, Folder 68, file "Commissione internazionale per l'esplorazione scientifica del mare mediterraneo - Institut Oceanographique" 1914-1940.
} 
the Institute of Marine Biology in Messina, or rather the central laboratory of RITC that Volterra and Grassi had advocated since 1909, was opened.

The ceremony was attended by director Luigi Sanzo, Grassi, representing the Accademia Nazionale dei Lincei, and the Navy Minister Pasquale Leonardi-Cattolica, as the first Chairman of the RITC. In his speech, Sanzo emphasised the technological aspects of the Institute, which was a first-rate station hosting a number of aquariums and laboratories, a library, a storeroom for instruments and reactants, as well as a sector dedicated exclusively to fish farming. (Sanzo 1916). Grassi took the floor to underline how the opening of the Station finally laid the foundations for a technical-scientific study of natural resources in Messina and for them to be used to benefit the economic progress of the country (Grassi 1916). On his part, Leonardi-Cattolica stressed the need to set up a fishing school annexed to the Institute (Leonardi -Cattolica 1916).

Volterra on the other hand started his speech by laying bare a deep, sincere, national feeling, underlining the fact that the Institute had finally:

"satisfied the desire of all those who feel the great importance of the development of an industry such as fishing for the richness of the country, which is awaiting its rational growth from systematic research and the combined efforts of biologists, industrialists and seafarers [... ] Italy is essentially a maritime power and the sea is its direction and its future". (Volterra 1916: 12)

Volterra concluded his speech by saying that the Institute in Messina "bears worthy comparison with the Station in Naples," which had been delivered from the influence of the Dohrn family, or as he put it "released from any German subjection and openly Italian" (Volterra 1916: 12). In fact, following Italy's entry into the war in 1915, the Station had been deprived of its director, Rinaldo Dohrn, the founder Anton's son, who had moved to Switzerland along with all the German personnel. ${ }^{11}$ Therefore the zoological station in Naples fell under the influence of the RITC.

Everything therefore seemed in place to complete the ambitious programme that the RITC had been carrying out over the years. By virtue of this programme, the RITC had become an essential point of reference for specialists in this field of studies, a fact stressed by Louis Joubin, a professor of marine biology at the Oceanographic Institute in Paris and first Director of the Office Scientifique et Technique des Pêches Maritimes. Following the opening in Messina, he published lengthy, flattering accounts in Bulletin de l'Institut Océanographique (Fondation Albert I, Prince de Monaco) and in Annales de Géographie in 1918 and presented the RITC and Messina's Institute as successful models to be exported abroad (Joubin 1918a, 1918b).

\footnotetext{
${ }^{11}$ See, Vito Volterra's Archive, Folder 68, file "Stazione zoologica di Napoli".
} 


\section{Volterra and the International Commission for the Scientific Exploration of the Mediterranean Sea}

After the war, from November 17-20, 1919, the ICESM was at last able to hold its Constitutive Assembly (2nd Plenary Assembly Meeting) in Madrid, following preparatory meetings in Rome (1914) and in Paris (June, October 1919). Opening the discussion, Prince Albert I expressed his satisfaction with the collaboration agreements that were finally becoming operative. After thanking his main companions in adventure - namely Volterra ${ }^{12}$, Vinciguerra, and others - he proceeded to inform the assembly of the interest that the newly formed International Research Council (or IRC, currently the International Council of Scientific Unions) (Greenaway 1996) had shown in the ICESM's work (Prince Albert I 1920).

The IRC was a body to coordinate international efforts in the different branches of science, requested by the allied countries that had won the First World War, with headquarters in Brussels. The IRC was comprised of several international committees, one for each scientific discipline, which were to be complemented at the country level by national committees. In Italy, this national committee is known as Consiglio Nazionale delle Ricerche (National Research Council, NRC) and was founded by Volterra in 1923, with headquarters in Rome, close to the Accademia Nazionale dei Lincei, which was the most important Italian cultural institution at that time.

It was certainly no coincidence that between 1918 and 1919 Volterra had been one of the co-founders of IRC and one of its Vice-Chairman, in the capacity of Director of the UIR. What needs to be underlined is that one of the international regulatory bodies in the framework of the IRC, the International Geodetic and Geophysical Union (IGGU), included a Physical Oceanography Department (POD) headed by Prince Albert I as Chairman of ICESM, and with Volterra representing Italy as Vice-President of the RITC.

Volterra played a leading part in laying the organisation of future international work in the field of physical oceanography. The main steps in this process were:

1. The plenary meeting of the Physical Oceanography Department held in Paris on 25 January, 1921 under the chairmanship of Prince Albert I, in which several major commissions for the study of the Atlantic, Pacific and Indian Oceans were set up, while agreements regarding the Mediterranean were reached with ICESM in accordance with a plan that had first emerged during the Madrid meeting in 1919.

2. A series of meetings both of the Head Office of the ICESM and of the Physical Oceanography Department held in Paris at the Oceanographic Institute from 1921 to 1922 (Richard 1921, 1922), during which the plan to publish a Multilanguage oceanographic dictionary, an international workbook for the oceanographic research, a series of

\footnotetext{
${ }^{12}$ Volterra was in America because of an invitation received by the Hitchcock Committee of Berkeley and did not return to Europe in time to attend the meeting in Madrid.
} 
monographs intended to make up an Oceanographic encyclopaedia was proposed. This proposal was refined and approved over the following years during Volterra's presidency of ICESM (1923-1928). ${ }^{13}$

3. As far as the scientific content was concerned, every decision was deferred to the first plenary meeting of the International Geodetic and Geophysical Union, scheduled to take place in Rome in May $1922,{ }^{14}$ in the headquarters of the Accademia Nazionale dei Lincei, under the direction of Volterra.

At the meeting of the IGGU in Rome, it was decided to promote the cooperation of biologists and the Physical Oceanography Department of IGGU was subsequently renamed Oceanographic Department. ${ }^{15}$

Volterra took advantage of the international stage to focus his attention on a project that was especially close to his heart, namely the creation of an Oceanographic Institute in Rome as a national centre similar to Paris's Oceanographic Institute, conceived as a high-level cultural body located inside the Accademia Nazionale dei Lincei, with both national scientific and applicative aims.

The project emerged as part of a law aimed at a general reorganization of the Italian fishing industry that was upheld by Volterra and others in the Italian Parliament in 1920 (Volterra 1920a, 1920b). To serve its purpose the Italian Oceanographic Institute was planned as a multifunctional institution divided into different sections. One section was to be devoted to research; another to university level teaching of oceanography; another one was to be devoted to circulating knowledge of oceanographic science among the public at large with conferences and the creation of a Fishing's Museum; finally, a fourth section was dedicated to the transfer of scientific knowledge to the country's industrial network by the Istituto centrale di idrobiologia (Central Institute of Hydrobiology) under construction at the time and supported by the Ministry of Agriculture. ${ }^{16}$ But the Accademia Nazionale dei Lincei, which feared that an

\footnotetext{
${ }^{13}$ See "Sur la publication du Manuel international pour les recherches Océanographique á la mer, du Vocabulaire océanographique, et de l'Encyclopédie océanographique. Extrait du procés-verbal de la réunion de Prague Séance du 8 Septembre 1927", CNR's Archive, Archivio centrale dello Stato, Rome, I versamento, Folder 185.

${ }^{14}$ Vito Volterra's Archive, Folder 73, file "Roma. Congresso delle Unioni internazionali Astronomica e Geodetico geofisica" 1922.

${ }^{15}$ As a consequence, the Biological Oceanographic Department which had been established within the International Union of biological sciences was abolished. Prince Albert I was chosen as the manager of the Oceanographic Department, which was in any case to remain within the IUGG. After his death in 1922, the Spanish Odon de Buen, director of the Oceanographic Institute in Madrid and promoter of the ICESM, was designated as the new head of the Oceanographic Department.

16 The negotiations to create the Central Institute of Hydrobiology had been brought about in 1920 by Magrini and RITC member Gustavo Brunelli. In regards to certain aspects, this body was a competitor of the one planned by Volterra especially because it took shape as a state-run consultancy centre closely connected to the Ministry of Agriculture alone. This Institute was set up in 1926.
} 
agreement of this kind could have compromised the totality of its autonomy, delayed the successful realisation of this institute-project. ${ }^{17}$

The failure to create an oceanographic institute in Rome was a heavy setback for the work of the RITC, despite Volterra's best efforts and his growing national and international prestige. In the early twenties in fact, Volterra's institutional career peaked. He was elected Vice-President of the Accademia Nazionale dei Lincei in 1920, and President of the International Bureau of Weights and Measures in 1921. In 1923, he became President of the Accademia Nazionale dei Lincei and in 1924 of NRC (Simili 2001a), of which he had been a promoter since 1919, as national partner of the IRC. In 1923, after the death of Prince Albert I in June 1922, Volterra took over as Chairman of the ICESM.

However, Volterra's research and institutional action soon encountered political obstacles. The first defeat had been the loss of the Zoological Station in Naples, which was returned to the Dohrn family in 1920 by the intervention of the philosopher Benedetto Croce, the Minister of Public Education, despite vibrant protests from Volterra (Volterra 1920c, Andreozzi 2000). The second defeat was an acute financial crisis that was slowing down RITC's proactive force as shown by the budget for the years1924 and 1925 prepared by Bonaldo Stringher - the RITC's Treasurer and Governor of the Bank of Italy. ${ }^{18}$ At last, the Government stopped funding the RITC, but this time due to serious political reasons.

In 1922 Benito Mussolini came to power in Italy, and Volterra was an outspoken opponent of his government. Between 1924 and 1925, Volterra realized that Fascism was changing into a dictatorial regime, and in 1925 he was one of the principal signatories of the Intellectual Declaration against Fascism proposed by Croce. From 1925 to 1929 Fascism became a dictatorship, with the eradication of parliamentary prerogatives and all powers placed in the hands of the executive branch of government, guided by Mussolini. The regime began a phase of strict control of culture in general and, in particular, of the scientific community.

Because of his opposition Volterra was driven out of Italy's scientific establishment and ostracized from his profession. In 1926 he was not reappointed as Chairman of either the CNR or the Accademia Nazionale dei Lincei. The NRC was reformed, and it became an organ at the service of the Fascist state, now chaired by the Nobel Laureate in Physics Guglielmo Marconi, personally appointed by Mussolini. In 1929 the RITC lost its independent status and became an integral part of the Fascist NRC. The author of this transition was the secretary Magrini, a supporter of Fascism from the start, who had understood well that the best way to guarantee that the RITC

\footnotetext{
${ }^{17}$ See "Per la fondazione di un Istituto oceanografico italiano a Roma", CNR's Archive, I versamento, Folder 185.

${ }^{18}$ The only notable activities were the ICESM's oceanographic campaigns that were carried out by the Italian scientific vessels known as the Tremili and the Marsigli in order to explore the Bosphorus, the Strait of Messina and the Red Sea. The other Member States on behalf of the Commission were the Giralda from Spain surveying the Strait of Gibraltar and the French vessels La Perche et l'Orvet, which focused their investigations on the Gulf of Gabes.
} 
received special attention from the government was to transform it into a consultative technical body of the government itself. ${ }^{19}$ By virtue of the new law, ${ }^{20}$ as Chairman of the CNR Marconi assumed control of the new-look RITC, while Magrini was unsurprisingly elected Vice-Chairman.

\section{An Outbreak of Ideas and an Institutional Decline}

Volterra reacted to the political persecution by devoting himself to his scientific work with renewed intensity. To this phase of his life belong the fundamental contributions he made to biomathematics. In 1926 he formulated the mathematical laws of the struggle for life by a group of species living in the same environment in such a way that some devour others, and he published the best-known paper Variazioni e fluttuazioni del numero d'individui in specie animali conviventi (Variations and fluctuations in the number of individuals of coexisting animal species).

This publication was the continuation of the studies carried out by Umberto D'Ancona, the zoologist/biologist who was the son-in-law of Vito Volterra and who had embarked on his scientific career at the RITC. Spanning the period 1905-1923 and including North Adriatic harbours such as Venice and Rijeka, the aforementioned surveys showed a large increase in the percentage of predator fish in total catch during WWI and the years immediately following. These statistics allowed D'Ancona to evaluate the impact of an almost complete fishing standstill during the War. D'Ancona asked his father in-law to justify, from a mathematical point of view, these mysterious dynamics, since the idea that they were purely due to external causes, in this case a somewhat decreased fishing activity at the beginning of the war, was not convincing indeed. Why should the increase only concern predator but not prey populations?

In order to solve the problem, Volterrra first (simplified it by) divided the fish population in two large classes, namely prey and predators. In order to understand the way population $x$ evolves over time, Volterra initially assumed no interaction with other species. In this case, the increase of population $x$ would follow an exponential growth. However, the presence of predators modifies these dynamics, since the growth of the prey population is now also dependent on the number of encounters, in a time unit, between prey and predators. Volterra made similar considerations about the growth rate of the predator population. This clever technique allowed Volterra to determine the cyclic evolution of both populations, leading to a system of differential equations. In others words, the endogenous reasons are sufficient to justify the fluctuations in the number of prey and predators and their periodical variations. The exogenous effect of fishing still remains to be understood, as well as the

\footnotetext{
${ }^{19}$ See the letter from G. Magrini and P. Cattani to S.E. il Ministro della Marina, Rome July $31^{\text {st }}$ 1928, CNR's Archive, II versamento, Folder 722/1. See also the letter from G. Magrini to S.E. il Ministro della Marina, Roma giugno 1928, CNR's Archive, II versamento, Folder 231/1.

${ }^{20}$ Law no. $1179,27^{\text {th }}$ June 1929.
} 
reasons why its reduction had led, in the war years and after, to an increase in the number of predators. To this end, Volterra modified the previous equations in order to take into account the "fishing factor". As a result, he confirmed the empirical observations made by D'Ancona (Scudo and Ziegler 1978, Barigozzi 1979, Kingsland 1985, Israel 1991, 1993, Levin 1994, Andreozzi 2002).

Furthermore, Volterra tried to give a theoretical explanation for these fluctuations from the perspective of evolutionary biology. He subsequently maintained an active international network of relations in the field of mathematical biology, stressing the need for an interaction between mathematicians and biologists (Millán Gasca 1996, Israel and Millán Gasca 2002).

From the institutional point of view, the years of Volterra's chairmanship at ICESM were especially proactive as a result of the support of the General Secretary Edouard Le Danois. ${ }^{21}$ Voterra's main initiative was to elaborate a new statute that was able to safeguard both coordination with other bodies and the full autonomy and complete independence of ICESM especially with regard to the IRC. ${ }^{22}$ At the same time his intention was to establish regular contact with the ICES. Then, the seat of the Commission was transfered to the Oceanographic Institute in Paris in 1924.

In 1928 Volterra was forced by the Fascist regime to resign from the ICESM, and from the vice-presidency of the IRC. However, the manoeuvres aimed at outing Volterra from the Chairmanship of ICESM were only partially successful.

Le Danois was firmly opposed to this ${ }^{23}$ and Volterra enjoyed the solidarity of his international colleagues. The matter was a political one and was resolved in a political way. In 1928 a new Chairman of ICESM was elected, ${ }^{24}$ but Volterra was acclaimed as Honorary Chairman. It should be pointed out, however, that Volterra was always absent at the nine sessions of the Head Office and the five plenary meetings held between 1928 and 1938. This absence became even more evident and loaded with symbolic meaning in 1933, when the delegations from ICESM member countries met in Italy for the third time in Naples Town Hall. Volterra retained the presidency of the International Bureau of Weights and Measures until his death in 1940.

In 1931 all the university professors were ordered to take an oath of fidelity to the Fascist government. Out of 1,200 university teachers only twelve refused to swear. Volterra was one of them. For this reason, he was deprived of his University chair. In 1934, an analogous oath was imposed on the members of academies and cultural institutions, and Volterra was declared debarred from all Italian academies (Goetz 1993). He spent a good deal of time in Paris

\footnotetext{
${ }^{21}$ Volterra's presidency of the ICESM (1923-1928) was marked by three General Assemblies held in Paris (1923), Madrid (1924), Venice (1926).

${ }^{22}$ The draft of the new statute was submitted and discussed during a meeting of the Head Office held in Paris on April $3^{\text {rd }} 1928$. [Procès-verbal de la séance du Bureau Central 1929a]. The statute was adopted in 1929 on the occasion of the Plenary Meeting of ICESM in Malaga. [Procès-verbal de la séance de l'assemblée pléniére et du Bureau Central 1929b]

${ }^{23}$ See the letter from Le Danois to V. Volterra, Paris le 8 Mai 1929, Vito Volterra's Archive, Folder 28

${ }^{24}$ He was the Italian Admiral Paolo Thaon di Revel.
} 
holding courses and conferences, but he never seriously considered the possibility of emigrating, though opportunities were not lacking.

In 1938, being a Jew, Volterra became the victim of anti-Semitic legislation, and Italian Jews suffered the humiliation to be banned from civic rights. Volterra died in Rome on October $11^{\text {th }} 1940$, a few months after Italy entered World War II on the side of Nazi Germany. It was to take six more years for his greatness to be officially acknowledged by a renewed republican and anti-Fascist Italy.

\section{Conclusion}

Voltterra's great achievements as a policy maker were the establishment of the ISAS in 1907, based on the model of similar associations already existing in more industrialized countries, such as the British Association for the Advancement of Science, and the establishment of the CNR in 1923

In this respect his main goal was to create a series of extramural institutes that were: 1) focused on experimental research rather than basic research, 2) worked in tight connection with the main industries, 3 ) directly financed by the Government, although maintaining their autonomy, 4) affiliated with international organization.

In this process the RITC's story marks an important step in the historical understanding of Volterra's institutional activity. The RITC nurtured Volterra's great interest in the applications of mathematics to the biological science and was the main reason why his activity was resumed in 1926 when he was involved in bio-mathematical research.

\section{References}

Albert I of Monaco (1920) Discours. Commission Internationale pour l'exploration scientifique de la mer Méditerranée [Speech. International Commission for the Scientific Exploration of the Mediterranean Sea]. 15 Janvier 1920. Conference de Madrid (17-20 novembre 1919). Bulletin de la Commission Internationale pour l'exploration scientifique de la mer Méditerranée 1(Nov. 1919): 1-22.

Andreozzi L (2000) Vito Volterra organizzatore scientifico e la nascita della biologia matematica in Italia [Vito Volterra scientific organizer and the birth of mathematical biology in Italy]. Nuncius. Annali di storia della scienza 15(1): 79-109.

Andreozzi L (2002) The history of theoretical population ecology: which role for mathematical modeling. In $\mathrm{P}$ Cerrai, $\mathrm{P}$ Freguglia, $\mathrm{C}$ Pellegrini (Eds.) The Application of Mathematics to the Science of Nature. Critical Moments and Aspects, 191-206. New York: Kluwer Academic/Plenum Publishers.

Barigozzi C (Ed) (1979) Vito Volterra Symposium on Mathematical Models in Biology. Proceedings of a Conference Held at the Centro Linceo Interdisciplinare, Accademia Nazionale dei Lincei, Rome December 17 - 21, 1979. Berlin: Springer.

Berget A (1910) Commission Internationale pour l'exploration scientifique de la mer 
Méditerranée. Procès-verbal de la réunion du 30 mars 1910, à Monaco [International Commission for the Scientific Exploration of the Mediterranean Sea. Minutes of the meeting of March 30, 1910, in Monaco]. Bulletin de l'Institut Océanographique (Fondation Albert I, Prince de Monaco) 167(Mai 1910), 1-14.

Berget A (1914) Commission Internationale pour l'exploration scientifique de la mer Méditerranée. Bureau Central. Deuxième réunion. Tenue à Rome le 3 février 1914, au Palis Corsini (Académie dei Lincei) [International Commission for the Scientific Exploration of the Mediterranean Sea. Central Office. Second meeting. Held in Rome on February 3, 1914, at the Palis Corsini (Academy of Lincei)]. Bulletin de l'Institut Océanographique (Fondation Albert I ${ }^{\text {er }}$, Prince de Monaco) 289, (Mars 1914), 1-19.

Goetze H (1993) Der Freie Geist und seine Widersacher [The Free Spirit and its adversaries]. Frankfurt am Main: Haag- Herchen Verlag GmbH.

Goodstein J (2007) The Volterra chronicles. The Life and times of an extraordinary mathematician 1860-1940. Providence, Ma: American Mathematical Society London Mathematical Society.

Grassi GB (1916) Discorso del senatore prof. Battista Grassi, membro del R. Comitato talassografico italiano, in rappresentanza dell'Accademia dei Lincei [Senator Speech prof. Battista Grassi, a member of the Italian R. Thalassographic Committee, in representation of the Academy of the Lincei]. Bollettino Bimestrale del R. Comitato Talassografico Italiano 6(39-44, Gennaio-Dicembre 1916): 19-20.

Greenaway F (1996) Science international. A history of the international council of scientific unions. Cambridge: Cambridge University Press.

Guerraggio A, Paoloni G (2013) Vito Volterra. Springer-Verlag Berlin Heidelberg.

Israel G (1991). Volterra's analytical mechanics of biological association (two parts). Archives Internationales d'Histoires des Sciences, 41: 57-104; 307-352.

Israel G (1993) The Emergence of Biomathematics and the Case of Population Dynamics: A revival of Mechanical Reductionism and Darwinism. Science in Context, 6, 469-509.

Israel G, Millán Gasca A (Eds.) (2002) The biology of numbers, the correspondence of Vito Volterra on mathematical biology. Basel: Birkhauser.

Joubin, L. 1910a. Projet d'entente entre les Stations maritimes de la Méditerranée pour l'établissement d'un plan commun de travaux océanographique. Bulletin de l'Institut Océanographique (Fondation Albert I ${ }^{\text {er }}$, Prince de Monaco) 164(Mars 1910), 1-5.

Joubin L (1910b) Plan de travaux océanographique à exécuter dans les stations maritimes adopté à Monaco par la Commission de la Méditerranée le $1^{\text {er }}$ Avril 1910 [Plan of oceanographic work to be carried out at sea stations adopted in Monaco by the Mediterranean Commission on 1 April 1910]. Bulletin de l'Institut Océanographique (Fondation Albert I ${ }^{\text {er }}$, Prince de Monaco 168) 164 (Mai 1910): 1-9.

Joubin L $\left(1918^{\circ}\right)$ Le comité royal thalassographique italien [The royal italian thalassographic committee]. Bulletin de l'Institut Océanographique (Fondation

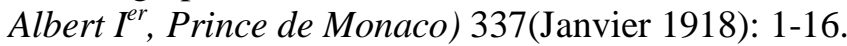

Joubin L (1918b) Le comité thalassographique italien et la station de Messine [The Italian thalassographic committee and the Messina station]. Annales de géographie 27(146): 81-91.

Kingsland SE (1985) Modeling nature: episodes in the history of population ecology. Chicago: University of Chicago Press.

Linguerri S (2000) La Società italiana per il progresso delle scienze: 1907-1930 [The 
Italian society for the advancement of science: 1907-1930]. Nuncius. Annali di storia della scienza 15(1): 51-78.

Leonardi-Cattolica P (1916) Discorso del senatore cav. Pasquale Leonardi Cattolica, viceammiraglio, in rappresentanza della R. Marina italiana [Senator speech Pasquale Leonardi Cattolica, Vice Admiral, representing the Italian Navy R.]. Bollettino bimestrale del R. Comitato talassografico italiano 6(39-44, GennaioDicembre): 15-17.

Levin S (Ed) (1994) Frontiers in mathematical biology. Berlin: Springer.

Linguerri S (2005) Vito Volterra e il Comitato talassografico italiano. Imprese per aria e per mare nell'Italia Unita (1883-1930) [Vito Volterra and Thalassographic Italian Committee. Companies in the air and sea in Italy in Unita (1883-1930)]. Firenze: Olschki.

Linguerri S (2014) L'oceanografia italiana sbarca in Europa: Vito Volterra e la "Commission internationale pour l'exploration scientifique de la mer Méditerranée [The oceanografia italiana sbarca in Europa: Vito Volterra and the International Commission for the Scientific Exploration of the Mediterranean Sea]. Giornale di Fisica, 55(1 Gennaio-Marzo):61-85.

Linguerri S (2015) Vito Volterra at the front: from the Office of Inventions to the Italian National Research Council. Lettera Matematica International Edition 3(1 June 2015): 53-61.

Magrini G (1910) Riunione in Venezia della Conferenza italo-austriaca per lo studio oceanografico- biologico dell'Adriatico (18-21 maggio) [Meeting in Venice, the Italian-Austrian Conference for the Adriatic oceanografico- biological study (1821 May)]. Bollettino del Comitato Talassografico 1, 4-5 (Maggio-Giugno 1910), 3-6.

Magrini G (1911) Verbali delle sedute della Commissione internazionale permanente per lo studio dell'Adriatico, Riunione di Monaco (2-6 maggio) [Reports of meetings of the Permanent International Commission for the Study of the Adriatic, the Monaco meeting (2-6 May)]. Bollettino bimestrale del R. Comitato talassografico italiano 2(11 Maggio-Giugno 1911): 98-110.

Magrini G (1916) Gli scopi e l'attività del R. Comitato talassografico italiano [The aims and activities of the Italian thalassographic committee]. Venezia: Tipografia Carlo Ferrari.

Mazliak L, Tazzioli R (2009) Mathematicians at war Volterra and his French colleagues in World War I. Dordrecht: Spinger.

Millán Gasca A (1996) Mathematical theories versus biological facts: a debate on mathematical population dynamics in the 1930s. Historical Studies in the Physical and Biological Sciences 26: 347-403.

Procès-verbal de la séance du Bureau Central tenue a Paris le 3 Avril 1928 (1929a) Rapports et procès-verbaux des réunions [Reports of meetings]. Commission Internationale pour l'Exploration Scientifique de la Mer Méditerranée 4(1929): 1722.

Procès-verbal de la séance de l'assemblée pléniére et du Bureau central, tenues á Malaga le 25 et le 26 avril 1929 (1929b) Rapports et Procès-verbaux des Réunions [Reports of meetings]. Commission International pour l'Exploration Scientifique de la Mer Méditerranée 4(1929) : 31.

Richard J (1921) Bureau Central de la Commission de la Méditerranée (Séance du 28 Janvier 1921) [Central Bureau of the Mediterranean Commission (Meeting of 28 January 1921)]. Bulletin de la Commission Internationale pour l'Exploration Scientifique de la Mer Méditerranée 6(Mars 1921): 1-4.

Richard J (1922) Conférence de Paris (13 Janvier 1922) [Paris conference (13 January 
1933)]. Réunion du Bureau Central. Bulletin de la Commission Internationale pour l'exploration Scientifique de la Mer Méditerranée 7(Mars 1922): 1-5.

Rozwadowski HM (2002) The sea knows no boundaries. A century of marine science under ICES. Seattle and London: University of Washington Press.

Sanzo L (1916) Discorso inaugurale del prof. Luigi Sanzo, direttore dell'Istituto centrale di biologia marina di Messina [Inaugural Speech of prof. Luigi Sanzo, director of the center of Messina Marine Biology]. Bollettino Bimestrale del R. Comitato Talassografico Italiano 4(39-44 Gennaio-Dicembre 1916): 25-43.

Scudo FM, Ziegler JR (1978) The golden age of theoretical ecology 1923-1940. Berlin: Springer.

Simili R (2001) La presidenza Volterra [The Presidency in Volterra]. In R Simili, G Paoloni Per una Storia del Consiglio Nazionale delle Ricerche, vol. I, 72-127. Roma-Bari: Laterza.

Simili R, Paoloni G (2008) Vito Volterra and the making of research institutions in Italy and abroad. In R Scazzieri, R Simili (Eds) The Migration of Ideas. Sagamore Beach, MA: Watson Publishing International LLC.

Smed J (2004) The founding of ICES- prelude, personalities and politics Stockholm (1899); Cristiania (1901); Copenhagen (1902). In M Selim (Ed), Ocean Sciences Bridging the Millennia. A Spectrum of Historical Accounts, 139-162. Unesco.

Verbali delle sedute della Commissione internazionale permanente per lo studio dell'Adriatico. Seconda riunione di Monaco (11-13 aprile) (1912) Bollettino Bimestrale del R. Comitato Talassografico Italiano 2(18 Luglio-Agosto 1912): 329-342.

Verbali delle sedute della Commissione internazionale permanente per lo studio dell'Adriatico. Terza riunione Monaco (2-5 maggio) (1913) Bollettino Bimestrale del R. Comitato Talassografico Italiano 3(23 Maggio-Giugno 1913): 59-70.

Verbali delle sedute della Commissione internazionale per l'esplorazione del Mediterraneo. Seconda riunione Roma (3-6 febbraio) (1914) Bollettino bimestrale del R. Comitato Talassografico Italiano 2 (27 Gennaio-Febbraio 1914): 7-21

Vinciguerra D (1908) Sull'opportunità di una esplorazione oceanografica del Mediterraneo nell'interesse della pesca marittima [On whether an oceanographic exploration in the interests of the Mediterranean sea fishing]. Bollettino della Società Geografica Italiana 9: 854-861.

Vinciguerra D (1910) Le riunioni scientifiche in occasione dell'inaugurazione del Museo oceanografico di Monaco [The scientific meeting for the inauguration of the Oceanographic Museum of Monaco]. Bollettino della Società Geografica Italiana, 2: 630-634.

Volterra V (1901) Sui tentativi di applicazione delle matematiche alle scienze biologiche e sociali [On attempts of application of mathematics to the biological and social sciences]. In Volterra Opere Matematiche: Memorie e Note, Accademia dei Lincei, Roma, [1954-1962], 3: 14-29.

Volterra V (1916) Discorso del senatore prof. Vito Volterra vicepresidente del R. Comitato talassografico in rappresentanza del Presidente, Ministro della Marina. Bollettino bimestrale del R. Comitato talassografico 6(39-44 Gennaio- Dicembre 1916): 11-14.

Volterra V (1920) Parole pronunciate in Senato durante la discussione di un disegno di legge su provvedimenti in favore della pesca e dei pescatori. Atti parlamentari, Senato del Regno, Legislatura XXV, $1^{\circ}$ sessione 1919-1920, Discussioni, Tornata del 25 giugno 1920, 1, 931-932.

Volterra V (1920b) Parole pronunciate in Senato durante la discussione di un disegno di legge su provvedimenti in favore della pesca e dei pescatori [Words spoken in 
the Senate during the discussion of a bill on measures in favor of fisheries and fishermen]. Atti Parlamentari, Senato del Regno, Legislatura XXV, $1^{\circ}$ Sessione 1919-1920, Discussioni, Tornata del 7 dicembre 1920 2: 2076-1078.

Volterra V (1920c) Sui criteri seguiti dal Governo nel togliere con decreto-legge la qualità di ente morale alla stazione zoologica di Napoli e nel restituirla ad un cittadino germanico, senza il consenso del Comune di Napoli proprietario della stazione stessa, e con grave danno dell'interesse e della dignità italiana [On the criteria used by the government to take out a decree-law the quality of moral authority to the Zoological Station in Naples and in return it to a German citizen, without the consent of the City of Naples owner of the station, and with severe damage and interest Italian dignity]. Atti parlamentari, Senato del Regno, Legislatura XXV, $1^{\circ}$ sessione 1919-1920, Discussioni, tornata del 9 dicembre 1920 2: 2130- 2135.

Volterra V (1926) Variazioni e fluttuazioni del numero d'individui in specie animali conviventi. In Volterra, Opere matematiche. Memorie e note, 5: 1-111. 
